\title{
US plans a multi-million dollar boost to computer simulation
}

[WASHINGTON] Universities and government laboratories in the United States are vying for leadership of a major research initiative in the scientific simulation of complex problems and other areas of computer technology.

The initiative, intended to secure US leadership in this area, will involve new expenditure of around $\$ 200$ million in its first year, rising to as much as $\$ 1$ billion a year thereafter. It is likely to be announced in President Bill Clinton's State of the Union address in January, and will form the main science and technology component of his budget proposal for the year 2000, to be presented to Congress in February.

The Department of Energy is preparing one aspect of the initiative, which will provide its non-weapons laboratories with supercomputer hardware and expertise for scientific simulation. Ernest Moniz, the under-secretary of energy, wants to give civilian scientists access to computers as powerful as those being installed at the US nuclear weapons laboratories, and has been vigorously pursuing the project since his appointment last December (see Nature 390, 651; 1997).

However, Clinton was told this summer that the National Science Foundation (NSF), which has no laboratories of its own and supports research through grants to universities, is best equipped to lead a major initiative in information technology - including scientific simulation. The industry-dominated President's Information Technology Adviso-

ry Committee (PITAC) advised Clinton that the NSF should coordinate federal computing research, and receive half the money for the new initiative.

Researchers could use the high-speed computer capability developed under the initiative to study problems as diverse as global climate change and the transport of radionuclides and other pollutants through soil and rock - an important priority at the Department of Energy, which is responsible for the clean-up of the US nuclear weapons production complex.

Structural biologists, combustion engineers and a host of other scientists and engineers interested in complex, three-dimensional problems could also use the capability.

In the next three weeks Neal Lane, the director of the White House Office of Science and Technology Policy (OSTP), will tour the facilities likely to be involved, and draw up a proposal for inclusion in the year 2000 budget; it must be submitted to the White House's Office of Management and Budget for approval by the end of November. But discussions are still taking place over how much money should be spent on supercomputers and other new facilities, and how much distributed to researchers for computer research or for developing scientific applications.

Although the proposal "is still halfbaked", it will take shape over the next two or three weeks, says one White House official. In addition to the Department of Energy and the NSF, the initiative will involve the National Institutes of Health, the space

\section{Biomedicine wins British budget top-up}

[LONDON] The biomedical and environmental sciences emerged as clear winners in the British government's longawaited share-out of an extra $\mathfrak{E} 313$ million (US\$531 million) in research funding over the next three years, announced this week.

The areas on which most of the extra funds will be spent include genome research, ageing, climate change, information technology and communications, and the social sciences.

The Medical Research Council will receive an additional $£ 90$ million between 1999 and 2002, which will mean a 6.8 per cent increase in real terms over its $\mathfrak{E 2 9 0}$ million budget for this year.

The Biotechnology and Biological Sciences Research Council is to receive an extra $\mathfrak{E} 52$ million, a 4 per cent increase over the same period. And the Natural
Environment Research Council gets an extra $\mathfrak{E} 40$ million, meaning a 3 per cent increase between 1999 and 2002 .

The Engineering and Physical Sciences Research Council will receive an additional $\mathfrak{E} 86$ million over the three years, amounting to a 3.5 per cent increase. But $\mathfrak{E} 60$ million of this must be used to support the work of the biomedical and environment research councils in areas such as bioinformatics and combinatorial chemistry.

The Particle Physics and Astronomy Research Council gets an extra $£ 20$ million, which will mean only a 0.55 per cent increase over three years. The government will reserve $\mathfrak{E} 30$ million as protection against currency fluctuations for international subscriptions, such as that to the European Laboratory for Particle Physics (CERN) in Geneva. Ehsan Masood

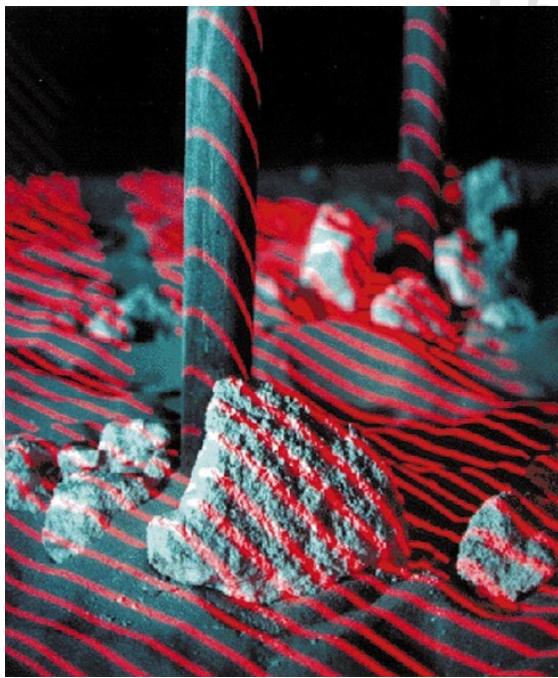

Down to detail: mapping the contents of nuclear waste tanks - as here at Hanford — is one task that is made easier by computer modelling.

agency NASA, the National Oceanic and Atmospheric Administration and the Defense Advanced Research Projects Agency.

"We're in the middle of an inter-agency discussion trying to move this forward," says Moniz. He says that, although the NSF will lead the overall initiative, the Department of Energy and NSF will have a "joint and equal" role in its simulation component.

Moniz points out that PITAC recommended extra funding of $\$ 200$ million annually over five years until the overall initiative was worth $\$ 1$ billion a year. It said this would double investment in basic research in information technology. "I'm not going to get into the numbers, but that is the scale that is being talked about," says Moniz.

Bill Madia, director of the Pacific Northwest National Laboratory in Washington State, one of the energy department laboratories set to be involved, says the simulation initiative itself will be worth \$150-\$200 million.

Government officials say the PITAC study appears to have settled any argument about whether the US computer industry needs government help with research and development. "PITAC was quite clear that fundamental innovations in computing come out of federally supported research in the universities," says one OSTP official.

However, there is some scepticism in Congress over the need for the additional spending. Past Clinton initiatives in this sphere - including the Next Generation Internet project — have been attacked on Capitol Hill as ill defined. Colin Macilwain 